\title{
The impact of the structural features of the rock mass on seismicity in Polish coal mines
}

\author{
Renata Patyńska ${ }^{1 *}$ \\ ${ }^{1}$ Central Mining Institute, 40-166 Katowice, Poland
}

\begin{abstract}
The article presents seismic activity induced in the coal mines of the Upper Silesian Coal Basin (GZW) in relation to the locations of the occurrence of rockbursts. The comparison of these measurements with the structural features of the rock mass of coal mines indicates the possibility of estimating the so-called Unitary Energy Expenditure (UEE) in a specific time. The obtained values of UEE were compared with the distribution of seismic activity in GZW mines. The level of seismic activity in the analysed period changed and depended on the intensity of mining works and diverse mining and geological conditions. Five regions, where tremors occurred (Bytom Trough, Main Saddle, Main Trough, Kazimierz Trough, and Jejkowice and Chwałowice Trough) which belong to various structural units of the Upper Silesia were analyzed. It was found out that rock bursts were recorded only in three regions: Main Saddle, Bytom Trough, and Jejkowice and Chwałowice Trough.
\end{abstract}

\section{Introduction}

The key problem in the mining science and practice is the progress in identifying the direct causes of the occurrence of a rockburst, especially in the phase of the occurrence of this dynamic impulse due to a seismic tremor [1-11]. Then, more effective preventive measures against rockbursts can be performed [12]. Seismic events and related seismic hazards in a given field are determined by a number of natural and technical factors [4].

The detailed knowledge of the structural features of the rock mass of coal mines of the Upper Silesian Coal Basin (GZW) should be a necessary factor for proper assessment of seismic and rock burst hazards and proper design of exploitation [5, 13].

It is becoming clear that, by proper location of the operation in relation to the direction of the fracturing of the rock mass, seismic hazards can be affected and reduced in the entire cycle of exploitation work [12]. It is introduced by the Unitary Energy Expenditure (JWE, $\mathrm{J} / \mathrm{t}$ ), defined as the ratio of seismicity induced by the operation of mines in a given year [14].

\footnotetext{
*Corresponding author: rpatynska@gig.eu
} 


\section{Seismicity of structural units of the Upper Silesian Coal Basin}

The analysis of seismic activity distribution in the years 2007-2016 for individual GZW structural units indicates that the tremors are generated by mining operations and are located in five regions: Bytom Trough (NB), Main Saddle (SG), Main Trough (NG), Kazimierz Trough (NK), and Jejkowice and Chwałowice Troughs (NJ) [15-18]. Data obtained in the location of the rockbursts indicate that these events occurred only in three regions of the GZW:

- 11 rockbursts - Main Saddle (SG), including the following mines: Wujek, Śląsk, Bielszowice, Pokój, Staszic, Halemba - Wirek, Mysłowice -Wesoła,

- 2 rockbursts - Bytom Trough (NB), including the following mines: Piekary, Bobrek Centrum,

- 8 rockbursts - Jejkowice and Chwałowice Troughs (NJ), including the following mines: Rydułtowy - Anna, JAS - MOS, Borynia- Zofiówka -Jastrzębie and Marcel.

The largest number of tremors (11) was recorded during the exploitation of seams deposited in the north and central wing of Main Saddle (SG). The tremors occurring during mining works in the northern and central wings of the Upper Silesian Coal Basin are mainly related to exploitation of the saddle group, which are covered by thick and strong rock layers [7].

The total number of 507 rockbursts recorded in the years 1970-2016 [16], as many as 470 cases occurred in the 500 group seams, including 194 seismic events in the 510 seam.

The data show that of 21 rockbursts (in the last 10 years), up to 13 cases occurred in the seams of the saddle (500), including 6 in the 510 seam. The remaining rockbursts were related to the seams of group 400, 3 seams of group 700 .

Referring the above-mentioned data to the rockbursts recorded in 2016, it is possible to say that there is a trend in the above-mentioned statistics. The effects of rockbursts that occurred in 2016, concerned the seam 507.

Analysis of rockbursts regions shows that these phenomena occur during the exploitation of deposits located at a considerable depth among compact rocks [4, 7].

With the increase in the depth of the longwall operation and the preparatory work, there is a systematic deterioration of geological and mining conditions. In connection with the drawing process of coal resources, the mines more and more often decide to conduct exploitation of deposits in areas with faults and/or in the area of former exploitation [6].

Among the reasons for deciding on the risk of rockbursts in the vicinity of mining works, the most frequently mentioned are:

- increase the depth of exploitation of coal seams,

- $\quad$ high degree of exploitation of the deposit,

- exploitation in residual areas of deposits,

- exploitation of local faults (possible to cross the front of mining works) and of a regional character,

- uneven selection of coal seams in the border areas of mines or between mining areas within one mine.

A detailed analysis of mining and geological conditions of the occurrence of rockbursts recorder between 2007-2016 has indicated that there is a link between the induced seismicity and the location of mining excavations in a particular GZW structural unit [15].

The importance of the formation of the equilibrium of the rock mass in the vicinity of the excavation is given in the geological form of the exploited bed, the properties of the rocks forming the bed, as well as - to a decisive degree - the susceptibility to fracture and rockiness of the rocks lying in the roof.

Research on the impact of faults and planes of reduced cohesion has revealed their association with seismic and rockburst hazards [15-17]. 
These determinations were made based on the analysis of rock bursts in the GZW coal mines in 2001-2015. The reported cases of rockbursts were, in particular (about 95\%) of the impact of the fault zones closest to the rockbursts, mainly (about 67\%) in local fault zones with discharge up to a dozen meters $(<12 \mathrm{~m})$. Only in 2 cases for 42 analysed rockbursts, there was no presence of a fault zone in the area impacted by the event.

In case of $43 \%$ of recorded rockbursts, the effects impacted the areas where works fronts were approaching fault zones. Only $10 \%$ of rockbursts were recorded at the fault and 5\% occured in the case of transitional faults with mining fronts.

It is clear from the data of the rock masses in the vicinity of troughs that $55 \%$ of the analysed cases showed effects in excavations at a distance of up to $100 \mathrm{~m}$ from the plane of the nearest fault. At a distance of 120 to $200 \mathrm{~m}$, there were only $22 \%$ rockbursts and $64 \%$ events over $220 \mathrm{~m}$.

Results of rock analysis obtained in specific geological and mining conditions, confirmed by the results of analytical tests, may be of general value only if they are consistent with the broadly understood mining activity. Therefore, for the verification of literary views, it is important to quantify the effects of natural discontinuities on the occurrence of rockbursts.

\section{Unitary Energy Expenditure in the conditions of mines threatened by rockbursts}

Analysis of Unitary Energy Expenditures (JWE, J/t) under the conditions of recorded seismic and troughs occurring in the GZW in the years 2007-2016, was based on archival rock data and digital records of seismic activity. Data on mining and recorded rockbursts [16-17] shows that, despite declining coal production in the last 10 years, the energy expenditure (JWE J/ton) has been on the upward trend by 2015 (Fig. 1).

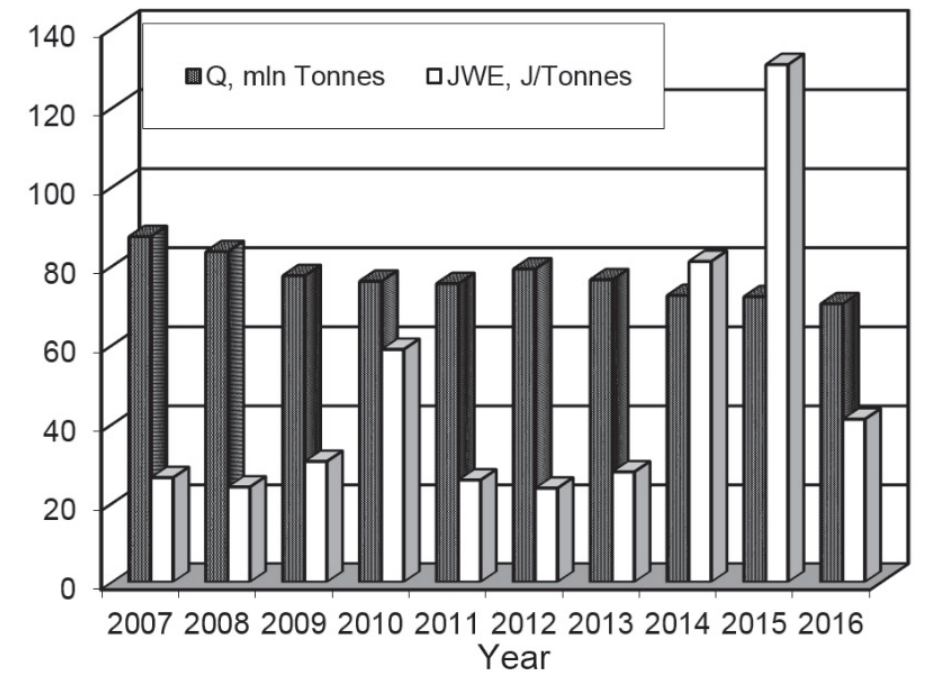

Fig. 1. Unitary Energy Expenditure compared to coal extraction in hard coal mines of GZW in 20072016.

Generated seismic activity is undoubtedly related to residual exploitation and, in particular, the concentration of mining and extraction works in the areas of impact residues and exploitation edges. This is evidenced by the fact that, with a steady downward trend in production from about 87.40 million tonnes in 2007 to 70.4 million tonnes in 2016 and a similar number of troughs in the same period: 1-5 a year (Fig. 2), the total seismic activity in 
2016, approximately $2.90 \cdot 10^{9} \mathrm{~J}$, was approximately $18 \%$ lower than the average value characterizing the years 2007-2016, $3.53 \cdot 10^{9} \mathrm{~J}$.

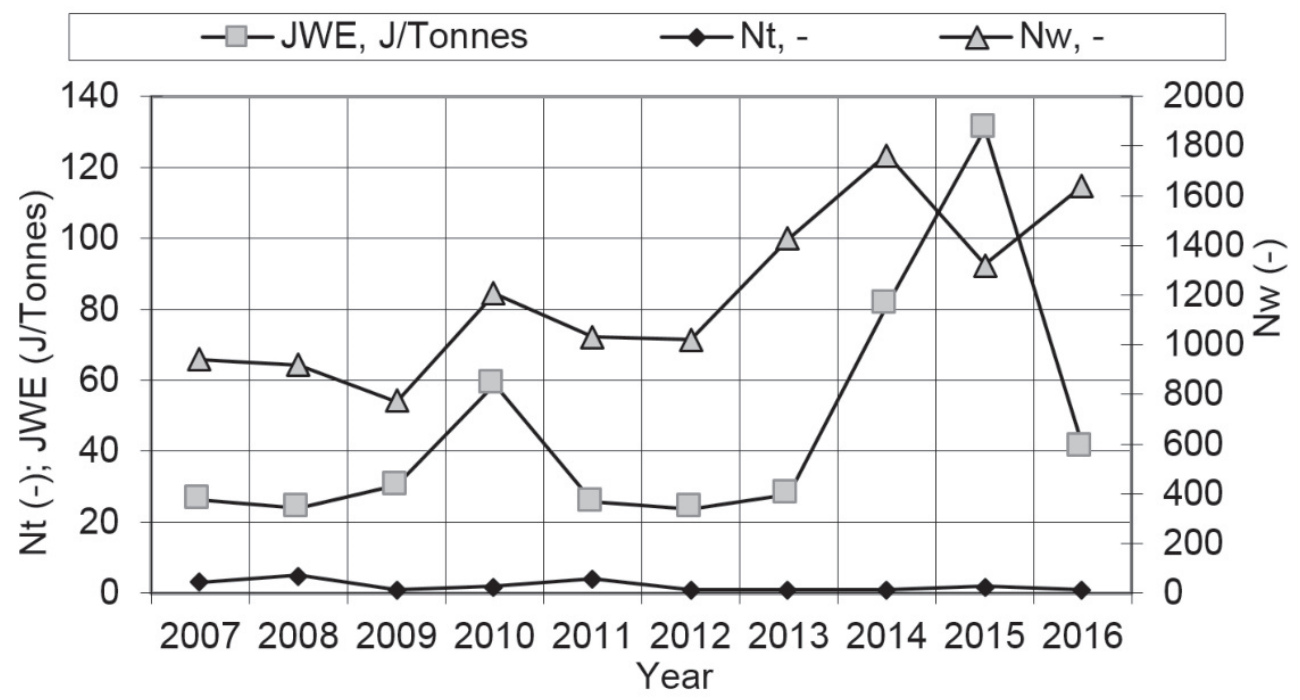

Fig. 2. Unitary Energy Expenditure compared to the number of rockbursts (Nt, -) and number of tremors (Nw, -) recorded in 2007-2016 in the GZW.

Below in Table 1, there are 21 treads against the size of the extraction, with extraction from areas that are at risk of rockbursts. It results from the fact that in the last 10 years total output has decreased by about $19.5 \%$, yet rock mining has increased by about $11 \%$. Half of the mines' output comes from areas subject to rockbursts and remains at $44-53 \%$ of total output. Despite a decline in total output in 2016, rock-bottom exploration increased slightly, but increased in particular from seams falling to grade III, which now accounts for about $12 \%$ of total output [16].

In order to demonstrate the relationship of the energy of rock mass to the mining operation of a given structural unit of the GZW rock mass, the Unitary Energy Expenditure was estimated for each area.

In total, in 2007-2016 there were 12,044 energy events of $E \geq 10^{5} \mathrm{~J}$, including 9,593 energy phenomena of $10^{5} \mathrm{~J}$, and 2,196 of $10^{6} \mathrm{~J}$. There were 228 energy events of $10^{7} \mathrm{~J}$, and 23 of $10^{8} \mathrm{~J}$. At that time, the recorded energy of 4 events amounted to $10^{9} \mathrm{~J}$ (Stec 2008-2017).

Although the mining operation over the past 10 years has covered the entire GZW area, rockbursts have been concentrated in five of its areas belonging to different structural units. The hypocentres show that the rock bursts have occurred in those areas where the deposits of coal are deep, and the layers are characterized by a high proportion of sandstone layers and strongly developed tectonics. They are: Main Saddle (SG), Bytom Trough (NB), Main Trough (NG), and Jejkowice and Chwałowice Trough, and Kazimierz Trough (NK.

Seismic activity in areas of mines where currently mining exploitation is not carried out, does not occur. On the other hand, recorded seismic activity in active mines, as the conditions of mining works deteriorate, increased. The most frequently mentioned causes include: increasing depth of exploitation, operation in fault zones, within the zones of protective pillars and near edges and debris.

The most active seismic was the area of the Kłodnica fault in the Main Saddle. Seismic activity in this region was mainly related to the mining operation carried out in ore and saddle layers. Rockbursts of the highest energy of $10^{8}$ and $10^{9} \mathrm{~J}$ occurred in the zone of the Kłodnica 
fault and the faults associated with the operation of the seams 418, 502, 507 and 510. In 2015, there was a rockburst of $4 \cdot 10^{9} \mathrm{~J}$, which is the strongest phenomenon in the GZW.

Table 1. Output, number and consequences of rockbursts in GZW in 2007-2016.

\begin{tabular}{|c|c|c|c|c|c|c|c|c|}
\hline Year & $\begin{array}{l}\text { Total } \\
\text { output, } \\
\text { mln } \\
\text { tonnes }\end{array}$ & $\begin{array}{c}\text { Output } \\
\text { form seams } \\
\text { with tremor } \\
\text { hazard, } \\
\text { mln tonnes }\end{array}$ & $\begin{array}{l}\text { Total } \\
\text { energy of } \\
\text { seismic } \\
\text { tremors, J }\end{array}$ & $\begin{array}{c}\text { JWE, } \\
\text { J/t }\end{array}$ & $\begin{array}{c}\text { Number } \\
\text { of rock } \\
\text { burst }\end{array}$ & $\begin{array}{c}\text { Rockburst } \\
\text { structural unit }\end{array}$ & $\begin{array}{c}\text { Number } \\
\text { of } \\
\text { structural } \\
\text { units in } \\
\text { which } \\
\text { rockbursts } \\
\text { occurred }\end{array}$ & $\begin{array}{c}\text { Total } \\
\text { output in } \\
\text { the mines } \\
\text { where the } \\
\text { rockburst } \\
\text { occurred, } \\
\text { mln tonnes }\end{array}$ \\
\hline 2007 & 87.40 & 44.60 & $2.31 \mathrm{E}+09$ & 26.41 & 3 & $\begin{array}{c}\text { Jejkowice and } \\
\text { Chwałowice } \\
\text { Trough (NJ) } \\
\text { Main Saddle (SG) }\end{array}$ & 2 & 5.84 \\
\hline 2008 & 83.60 & 41.90 & $2.01 \mathrm{E}+09$ & 24.04 & 5 & Main Saddle (SG) & 1 & 14.25 \\
\hline 2009 & 77.50 & 34.30 & $2.36 \mathrm{E}+09$ & 30.50 & 1 & Main Saddle (SG) & 1 & 2.49 \\
\hline 2010 & 76.10 & 35.80 & $4.48 \mathrm{E}+09$ & $\mathbf{5 8 . 8 4}$ & 2 & $\begin{array}{l}\text { Jejkowice and } \\
\text { Chwałowice } \\
\text { Trough (NJ) }\end{array}$ & 1 & 5.06 \\
\hline 2011 & 75.50 & 34.20 & $1.95 \mathrm{E}+09$ & 25.80 & 4 & $\begin{array}{c}\text { Jejkowice and } \\
\text { Chwałowice } \\
\text { Trough (NJ) } \\
\text { Main Saddle (SG) } \\
\text { Bytom Trough } \\
\text { (NB) } \\
\end{array}$ & 3 & 10.80 \\
\hline 2012 & 79.20 & 37.60 & $1.88 \mathrm{E}+09$ & 23.74 & 1 & $\begin{array}{l}\text { Jejkowice and } \\
\text { Chwałowice } \\
\text { Trough (NJ) }\end{array}$ & 1 & 2.75 \\
\hline 2013 & 76.47 & 36.90 & $2.13 \mathrm{E}+09$ & 27.86 & 1 & $\begin{array}{l}\text { Bytom Trough } \\
\text { (NB) }\end{array}$ & 1 & 1.04 \\
\hline 2014 & 72.50 & 36.00 & $5.88 \mathrm{E}+09$ & 81.10 & 1 & $\begin{array}{c}\text { Jejkowice and } \\
\text { Chwałowice } \\
\text { Trough (NJ) }\end{array}$ & 1 & 4.88 \\
\hline 2015 & 72.19 & 37.10 & $9.45 \mathrm{E}+09$ & 130.90 & 2 & Main Saddle (SG) & 2 & 4.34 \\
\hline 2016 & 70.40 & 36.90 & $2.90 \mathrm{E}+09$ & 41.19 & 1 & Main Saddle (SG) & 1 & 0.74 \\
\hline
\end{tabular}

Another area with high seismic activity was Bytom Trough, where seismic activity was associated with the operation of saddle and Poręba layers. In this area, very high seismic activity is observed. Outbreaks of events of energy greater than $10^{8} \mathrm{~J}$ were located in the axis of the trough at a depth of several hundred meters below the mining activity.

In the Main Trough seismic activity, seismic activity occurred during the exploitation of the layered layers in which the most active seismic seams were 207 and 209. The strongest event of $3 \cdot 10^{9} \mathrm{~J}$ energy occurred in this area during operation in seam 207.

The large number of events recorded in Jejkowice Trough was caused by the operation of Jaklowice layers, mainly seams 703, 712 and 713.

Due to the inactivation of the mining works in Kazimierz Trough, low seismic activity was observed with a small number of rockbursts, representing only $0.1 \%$ of the other GZW structural units.

Despite the comparable values of total energy of tremors recorded within the area of Bytom Trough $\left(5.48 \cdot 10^{9} \mathrm{~J}\right)$ and Jejkowice and Chwałowice Troughs $\left(5.55 \cdot 10^{9} \mathrm{~J}\right)$, the latter region is characterised by increased possibility of tremor due to the increasing number of tremors with higher energy values. 
The energy analysis of tremors which caused rock bursts between 2001 and 2015, in relation to the number of tremors, shows that:

- Bytom Trough (NB) - 4 rock bursts of total energy Et $=4.02 \cdot 10^{7} \mathrm{~J}$; average energy of a tremor that caused a rock burst amounted to about $1.01 \cdot 10^{7} \mathrm{~J} ; 1,492$ - total number of tremors

- Jejkowice and Chwałowice Trough (NB) - 10 rock bursts of total energy Et $=3.77 \cdot 10^{8} \mathrm{~J}$; average energy of a tremor that caused a rock burst amounted to about $3.77 \cdot 10^{7} \mathrm{~J} ; 2,991$ - total number of tremors.

- Main Saddle (SG) - 28 rock bursts of total energy Et $=4.78 \cdot 10^{9} \mathrm{~J}$; average energy of a tremor that caused a rock burst amounted to about $1.71 \cdot 10^{8} \mathrm{~J} ; 8164$ - total number of tremors.

Thus, in terms of rock burst hazard in the earlier mentioned regions, NB and NJ, the average energy of tremors that had resulted in a rock burst was comparable.

Probability of Rock Burst indicators: Bytom Trough $\left(\mathrm{PT}_{\mathrm{NB}}=0.00268\right)$ and Jejkowice Trough $\left(\mathrm{PT}_{\mathrm{NJ}}=0.00334\right)$ are comparable despite the fact that the number of rock bursts and tremors in Jejkowice and Chwałowice Troughs was twice as high as in Bytom Trough.

Both seismic hazards such as rockbursts, are more accurately determined by the Regional Rock Burst Indicator (RWT), which is defined as the dependence of the aggregate energy of the tides versus the total energy of the seismic shocks of a given year.

Table analysis shows that Regional Rock Burst Indicator applies only to the three structural units of Upper Silesian Coal Basin. The maximum value is reached with respect to the recorded seismic activity and the number of tremors that had caused rock bursts in the area of the exploitation of mines located within Main Saddle (SG). The next regions include: Bytom Trough, Jejkowice Trough, and Jastrzębie Fold Trough, which have a significantly lower RWT value.

Summing up the above, it should be stressed that the research showed that between 2001 and 2015 rock burst hazard in GZW mines included only the three areas.

Estimated Regional Rock Burst Indicator, which indicates the level of rockbursts hazard, showed a relatively high value for the Main Saddle $\left(\mathrm{RWT}_{\mathrm{SG}}=0.234\right)$, which clearly indicates a very high risk of rockbursts in the area of this structural unit.

Bytom Trough (NB), and Jejkowice and Chwałowice Trough (NJ) are characterised by lower RWT values $\left(\mathrm{RWT}_{\mathrm{NB}, \mathrm{NJ}}=0.007\right)$.

\section{Conclusion}

The analysis of the tremors and rock bursts catalogue stored in GIG's (Central Mining Institute in Katowice) archive allowed to conclude that:

- despite the declining hard coal production in the last 10 years, the energy expenditure (JWE J/tonnes) has shown an upward trend by 2015 ,

- despite the decrease in the number of rockbursts, the total value of their seismic energy, especially high energy rockbursts $>10^{5} \mathrm{~J}$, remains at the JWE average level (47.04 $\mathrm{J} /$ tonnes) of the last ten years,

- in general, the activity was subject to change and depended on the intensity of mining works and diverse mining and geological conditions of the region,

- seismic activity occurred in five regions of GZW, representing the following structural units: Bytom Trough (NB), Main Saddle (SG), Main Trough (NG), Kazimierz Trough (NK), Jejkowice and Chwałowice Trough (NJ),

- only three are classified as areas susceptible to rock bursts, they include: Main Saddle (SG), Bytom Trough (NB), Jejkowice and Chwałowice Trough (NJ), 
- the area characterised by the greatest seismic activity was Kłodnica Fault and associated faults in Main Saddle (SG). The maximum number of tremors was recorded in that region, including the events that caused rock bursts.

- another seismically active region characterised by a number of rock bursts is Jejkowice and Chwałowice Troughs (NJ), the smallest number of events was recorder in Bytom Trough (NB).

- in Main Trough (NG), despite high seismic activity, no tremors resulting in rock bursts were recorded.

Detailed studies on the impact of faults and the influence of fractures have shown their association with the risk of rock bursts and thus the seismic activity determined by the Unitary Energy Expenditure $(\mathrm{J} / \mathrm{t})$. These determinations were made based on the rockbursts statistics of the GZW coal mines.

\section{References}

1. B.H.G. Brady, E.T. Brown, Rock mechanics for underground mining, (University Press, Cambridge 1993)

2. E. Hoek, P.K. Kaiser, W.F. Bawden, Support of underground excavations in hard rock (Funding by Mining Research Directorate and Universities Research Incentive Fund, 1995)

3. Z. Pilecki, Dynamic analysis of mining tremor impact on excavation, Proc. Int. FLAC Symp. on Numerical Modeling in Geomechanics, Detournay \& Hart, 397-400 (Minneapollis, USA 1-3 Sept. 1999)

4. J. Dubiński, W. Konopko, Tapania-ocena, prognoza, zwalczanie (Wydawnictwo GIG, Katowice 2000)

5. J. Dubiński, Z. Pilecki, W. Zuberek, eds., Badania geofizyczne w kopalniach-przeszłość, teraźniejszość i zamierzenia na przyszłość (IGSMiE PAN, Kraków 2001)

6. Z. Burtan, Z. Rak, J. Stasica, Priorities in the development of mining systems in the mining sector in Poland, Gospod. Surowcami Min. 24, 1, 185-200 (2008)

7. W. Konopko, R. Patyńska, Warunki występowania tapnięć w kopalniach węgla kamiennego, Przegląd Górniczy 64, 1, 12-17 (2008)

8. J. Brodny, Determining the working characteristic of a friction joint in a yielding support, Arch. Min. Sci. 55, 4, 733-746 (2010)

9. J. Brodny, Tests of friction joints in mining yielding supports under dynamic load, Arch. Min. Sci. 56, 1, 209-227 (2011)

10. J. Brodny, Arch. Min. Sci. 57, 4 (2012) doi: 10.2478/v10267-012-0015-4

11. Z. Burtan, A. Zorychta, J. Cieślik, D. Chlebowski D., Arch. Min. Sci. 59, 3, 691 - 704 (2014) doi: 10.2478/amsc-2014-0048

12. A. Goszcz, Wybrane problemy zagrożenia sejsmicznego $i$ zagrożenia tapaniami kopalniach podziemnych (Biblioteka Szkoły Podziemnej Eksploatacji Złóż, Wydawnictwo Nauka Technika, Kraków 2004)

13. Z. Pilecki, Metoda oceny zachowania się masywu skalnego wokót wyrobiska podziemnego, Studia, Rozprawy, Monografie 59 (IGSMiE PAN, Kraków 1999)

14. R. Patyńska, Wpływ kierunku wybierania pokładu na jednostkowy wydatek energetyczny (JWE, J/t), XXVIII Zimowa Szkoła Mechaniki Górotworu i Geoinżynierii 437-450 (Oficyna Wydawnicza Politechniki Wrocławskiej, Wrocław 2005)

15. R. Patyńska, K. Stec, Aktywność sejsmiczna Górnośląskiego Zagłębia Węglowego a zagrożenie tapaniami w latach 2001-2015, Zeszyty Naukowe - Bulletin of the Mineral 
and Energy Economy Research Institute of the Polish Academy of Sciences 97, 135-144 (2017)

16. R. Patyńska, Zagrożenie tapaniami. Raport roczny o stanie podstawowych zagrożeń naturalnych i technicznych $w$ górnictwie węgla kamiennego, 88-100 (Wyd. GIG, Katowice 2008-2017)

17. K. Stec, Zagrożenie sejsmiczne. Raport roczny o stanie podstawowych zagrożeń naturalnych $i$ technicznych $w$ górnictwie węgla kamiennego, 72-88 (Wyd. GIG, Katowice 2008-2017)

18. R. Patyńska, K. Stec, Regional Rockburst Indicator for structural units of Upper Silesian Coal Basin, Studia Geotechnica et Mechanica 39, 2, 32-45 (2017)

19. E. Pilecka, Statystyczna analiza związku między położeniem epicentrów wysokoenergetycznych wstrząsów a lineamentami na obszarze Górnośląskiego Zagłębia Węglowego, Gospod. Surowcami Min. 23, 4, 101-109 (2007)

20. E. Pilecka, Z. Pilecki, Analysis of relation between induced seismic activity and satellite data. Proc. $19^{\text {th }}$ Symposium on Application of Geophysics to Engineering and Environmental Problems SAGEEP, EEGS, 346-355 (Seattle, USA, 2-6 April 2006) 